\title{
Increasing Compliance Of Public Institutions Within Implementation - The Constituent Of Public Information Transparency In West Aceh
}

\author{
Afrizal Tjoetra ${ }^{1}$, Sudarman ${ }^{2}$ \\ Departement of Sociology${ }^{1}$, Departement of Public Adminstration ${ }^{2}$, \\ Faculty Social and Political Science, Teuku Umar University, \\ Aceh Barat, Indonesia \\ atjoetra@gmail.com ${ }^{1}$,darman76alwy@gmail.com ${ }^{2}$
}

\begin{abstract}
Referring to the results of the evaluation of Commission on Information Aceh (Komisi Informasi Aceh-KIA) in 2013 and 2014 and then, known to the general implementation of UU KIP in Aceh has not been encouraging and is still required serious efforts to implement the provisions that have been defined. This research was conducted through a quantitative approach, with the survey method. The aims of research are to determine the readiness of the Public Institutions of West Aceh in implementing the constituent on Public Information, to investigate the Public Information Service in West Aceh Government in providing and announcing regular information and information immediately via the website / bulletin board at the Public Institutions, to know and see the direct efforts of the Public Institutions of West Aceh in preparing and providing the information available at any time to the applicant information, and to submit the feedback to the Public Institutions of West Aceh based on the results of research, so the strengthening of the main PPID and maid PPID in West Aceh. This research was conducted in three stages, namely through independent review, examination of the website and visits to the elected Public Institutions.
\end{abstract}

Keywords: Public Information Transparency, Public Institutions, Public Information

\section{INTRODUCTION}

Indonesian Government's efforts to carry out good governance and clean government become more noticeable. This is corroborated by the passing of the Public Disclosure Act (UU KIP) on 30 April 2008, whereas, the public disclosure is a must for the implementation of good and clean governance. In addition, public participation in the whole process of government is expected to further increase after the post-Suharto-reform to ensure that changes continue in the archipelago.

UU KIP or the Law on Freedom of Information No. 14 of 2008 consists of 16 chapters and 64 articles. General Explanation of the Law stated that the existence of UU KIP [2008] is very important as the legal basis relating to (1) the right of every person to obtain information; (2) Public Bodies obligation to provide and respond to request for information quickly, timely, low cost / proportional and simple way; (3) tight and limited exceptions; (4) Public Agency obligation to fix the documentation and information service system.
Furthermore, General Explanation of the Law [2008] also stated that every public agency has the obligation to open access to public information relating to the public agency for society at large. The scope of the Public Agency in the Freedom of Information Law includes the executive, judiciary, legislative, and other state apparatus that receive funding from state's budget (APBN)/ Provincial/District Budget (APBD) and also includes non-governmental organizations, whether it has or not a legal entity, such as nongovernmental organizations, associations, and other organizations that manage or use the funds partially or wholly sourced from APBN/APBD, community contributions, and / or abroad. The mechanism and the implementation of the principle of openness are expected to create good governance as well as transparency and accountability with high public participation as one of the prerequisites to realize the essentials of democracy.

This is consistent with Katherine and Susan (1998), which states that public participation is a fundamental element in the framework of good 
governance. In fact, the development indicates a necessity for the government (in the broad sense) to be more accountable to the people they represent about how the input of the community is used in policy formulation.

Furthermore, it is stated that the effectiveness of public participation requires the support of certain resources should be owned by the public and the government (Katherine and Susan, 1998). These resources are:

1) Changes in behavior and institution of government agencies. Traditional government institutions with long levels of hierarchical organization, formulation of policies based on the hierarchical ladder of authority, secrecy, monopoly of information, is a major obstacle to the implementation of public participation, which requires openness, flexibility, responsiveness and accountability.

2) Increasing the capacity of associations or public organizations. This increase should also be supported by the government, mainly through the program or allocation of funds.

3) Easy access for public to get information. Often the issue or issues raised by the public are not accompanied by accurate data, especially concerning government policies or programs, so that emotional factors predominate.

The Government of Aceh and it's Regencies / Cities have shown good commitment to implement public disclosure. This is realized by establishing a Documentation and Information Management Officer (PPID) Main and Assistant, at Working Unit of Aceh Apparatus (SKPA). This appointment made by Governor's Decree No. 480/335/2012. Furthermore, the Aceh Government also formed a Regulation on Guidelines for the Management of Information and Documentation for PPID through Aceh Governor Regulation No. 39 Year 2012. Then, the Aceh Government established the Commission on Information of Aceh (KIA) on June 19, 2012, by the Decree of the Governor of Aceh No. $555 / 389 / 2012$ as the implementation of the Freedom of Information Law.

In addition, the Circular of the Minister of Home Affairs No. 188.2/7266/SJ/2013 on the Acceleration of the Establishment and Operations of PPID of Provincial and District / Municipal, has been addressed by a number of Regent / Mayor in Aceh with the issuance letter of the appointment / designation of PPID at the district / city level. Until now, it has been established 23 PPID Regency/City, including in Aceh Barat District.

Nevertheless, the implementation of the Freedom of Information Law is still not maximized in accordance with applicable regulations. This is shown by a number of public information disputes before KIA on relevant information that is part of the obligation of public bodies. Referring to the results of the evaluation by KIA within three years (2013-2015), it showed that general implementation of Freedom of Information Law in Aceh has not been encouraging and is still required serious efforts to implement the provisions that have been defined. After that, it has also shown that there are low compliance, commitment and support of policy makers at the Department/Agencies as the Government Public Agency to implement the UU KIP. This is demonstrated by the lack of availability of services, limited budget to carry out the functions and activities of PPID, there is even a PPID which has not received any budget support from APBA/ APBK. In addition, the limited socialization UU KIP and Perki-SLIP (Commission of Information Regulation-Public Information Service Standards), so there are many public officials and managers at public agencies and the public has not been exposed to the existence of UU KIP (KIA, 2013 and 2015).

Efforts conducted by the Government of Aceh became an integral part of the general explanation of the Freedom of Information Law which states that the Constitution of the Republic of Indonesia Year 1945 Article 28F states "that every person has the right to communicate and obtain information to develop personal and social environment, and shall be entitled to seek, obtain, possess and store information by using all available channels ". To provide a guarantee to all men in obtaining information, it is necessary to establish laws governing the disclosure of public information. The maximum functionality is required given the right to obtain information is a basic human right as one manifestation of the life of a democratic nation and state.

Furthermore, it is stated that one important element in realizing open state governance is the 
public's right to obtain information in accordance with the legislation. The right to information is very important because the more open the state administration to public scrutiny, the more accountable its governance. The right of every person to obtain information is relevant also to improve the quality of community involvement in public decision making process. Participation or community involvement does not mean much without a guarantee of the openness of Public Information (General Explanation of UU KIP, 2008).

By opening public access to information, Public Agency is expected to be more responsible and service-oriented for the betterment of the people. Thus, it can accelerate the realization of an open government which is a strategic effort to prevent corruption, collusion and nepotism, and the creation of good governance.

A number of laws and regulations, both from the central government and Aceh, have been aimed at improving compliance of public bodies in implementing the UU KIP. However, the results of preliminary observations in general at the level of the Main PPID and Assistants (Work Unit of District Apparatus-SKPK) in West Aceh has drawback, among others:

1. Absence of the needed district regulation on the Standard Operating Procedures (SOPs) for the Assistants PPID in implementing the UU KIP.

2. Absence of List of Public Information (DIP) which is accessible to the public and list of the undisclosed.

3. Lack of public information services through the website in accordance with the provisions of Freedom of Information Law and Perki SLIP, especially information which must be provided on a regular basis, the information required at any time, as well as information that is excluded.

4. Main PPID and Assistant PPID largely unaware of facilities and infrastructure in implementing the Freedom of Information Law, such as adequate computers, desk, as well as other administrative support facilities.

For that reason, the researcher formulated the problems as follows:
1. What is the compliance of the Aceh Barat District Government through the Assistant PPID in implementing the UU KIP?

2. What may affect compliance of government officials in Aceh Barat District in implementing UU KIP?

Based on some of the foregoing, the researchers wanted to ensure increased compliance of public bodies in implementing the Law on Public Information in West Aceh district. This process as a form of support to the implementation of the Freedom of Information Law in Aceh Barat to takes place effectively, so that leads to the implementation of good and clean governance as well as increase public participation in development.

This study has two objectives, namely:

1. General Purposes; To improve compliance of the Government Public Agency in Aceh Barat District in implementing the UU KIP.

2. Special Purpose; The specific objective research on the implementation of the Freedom of Public Information.

Previous research has been carried out by the Information Commission of Aceh since 2013 to 2015 related to compliance of Public Agency in Aceh in implementing the Freedom of Information Law. The scope of the research was provincial level and the Main Documentation and Information Management Officer (PPID) of Regency/ City, Political Parties and State Universities. Based on the evaluation of the Public Agency in 2015, the Main PPID of Aceh Barat District ranked second out of 23 districts / cities in Aceh with a score of 55.92. Assessment result was an aggregate value of $S A Q$, website, and field visits (Komisi Informasi Aceh, 2015).

During the study on the Assistants PPID in Aceh Barat, the researchers utilize the same approach and questionnaire used by KIA in the evaluation of public agencies in Aceh. It's just has different coverage of public agencies, and focuses on the Assistants PPID of SKPK in Aceh Barat District. The establishment of the Assistants PPID was set out by the Decree of Bupati Aceh Barat Number 619 Year 2014 on The Appointment of Documentation and Information Management Officers within the Government of Aceh Barat 
District. The mentioned Assistants PPID of SKPK are of 35 departments/Agencies/Offices.

\section{RESEARCH METHODS}

This research was conducted through a quantitative approach with survey method. Survey research was conducted over 35 Assistants PPID of SKPK of the Government of Aceh Barat District. The survey method was conducted as a complete survey or census. Normatively, the survey is used to describe the data of the object of study, interpret and analyze systematically.

1. Location and Time Frame; Location of the study conducted in West Aceh district, with a sample of 35 Assistants PPID at the SKPK of West Aceh District Government. The study began in May until November 2016.

2. Types and Sources of Data; This research is a case study with the primary and secondary data types. In this study the primary data is a direct response from the informant relating to the perception of the PPID towards the UU KIP. Primary data aims to meet the needs of the research. The primary data as said by Bagong Suyanto and Sutinah (2008, p. 55) that "the primary data obtained directly from the object to be examined (the respondent)."

The primary data collection using research instruments, namely the interview guide and unstructured interview. Meanwhile, according to Bungin (2008, p. 122): "Secondary data is data obtained from a secondary source of data we need, for example through a document". The secondary data is data obtained by researchers from sources that already exist. It is known that prior to the study conducted by the researchers, secondary data is already available, the data obtained from the study of literature, documents, reports, related to the research study.

In this study, secondary data is data from the literature such as reports and books related to the perception of the PPID towards the UU KIP.

\section{Method of Data Collecting}

This Public Agency research process is divided into two stages, namely:

1. The first phase is called self-assessment by the Public Agency. At this stage, researchers sent a questionnaire to be filled by PPID in the Public Agency, and subsequently verification PPID website conducted in relation to liabilities of periodic publication of information.

2. The second phase is called field visit. At this stage, the researchers set a number of selected public bodies in accordance with the determination of the initial ranking and then to take $(10 \%-15 \%)$ public bodies who were nominated.

\section{Research Instrument}

The public agency research instrument is a measuring instrument developed in the form of a table containing a list / check list which contains questions and sentences to determine and ensure PPID Public Agency to implement or not the standard provision of public information services as required by the Freedom of Information Law and Information Commission Regulation on Standards Public Information services (Perki SLIP, 2010).

This Public Agency Compliance research instruments in West Aceh district is comprised of:

a) Self Assessment Instrument (Self Assessment Questionnaire/SAQ).

b) The instruments of assessment and verification of Public Agency website in West Aceh district.

c) Visitation instruments, namely checklists used during field visits to the Public Agency of West Aceh district government to measure the availability of information at any time and information services by the PPID (supply and serve variables).

In the evaluation of government officials and government public agency, 3 (three) indicators are used as follows: 
1. Means of information services (Information Desk, Information Officer, notice board)

2. Reports of public information services to the Information Commission

3. Development of information systems

General scheme checklist/ questionnaire as follows [10]:

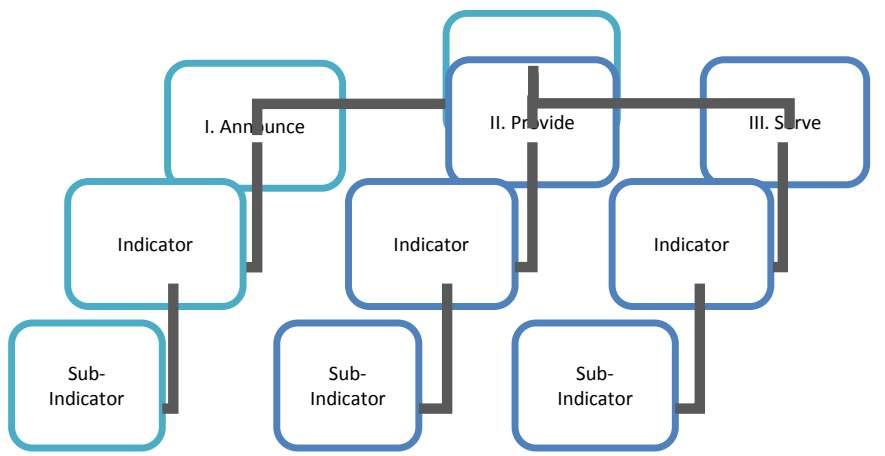

The following scheme describes the evaluation conducted in compliance assessment of Public Agency in Aceh Barat in implementing the UU KIP through stage 1 and stage 2:

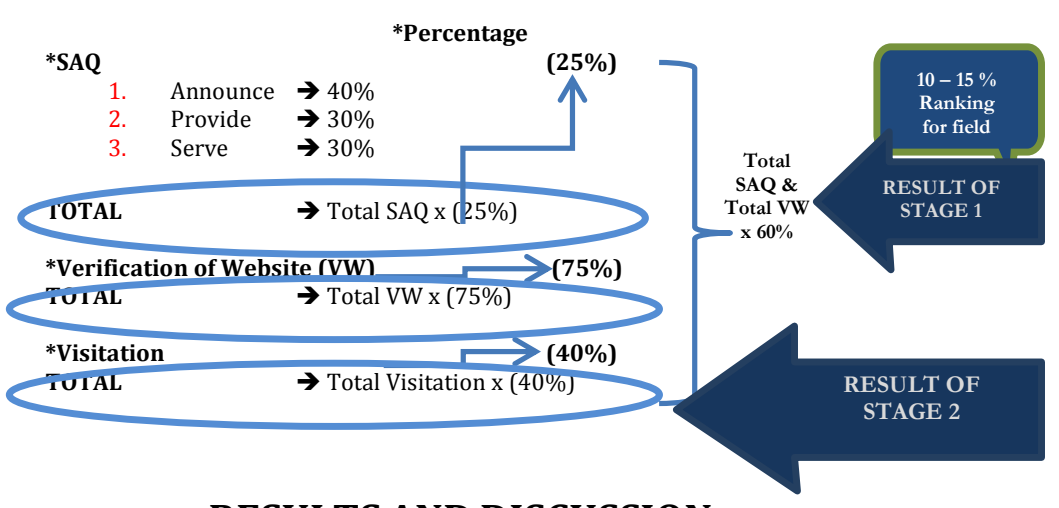

Total SAQ Score of SKPK in Aceh Barat

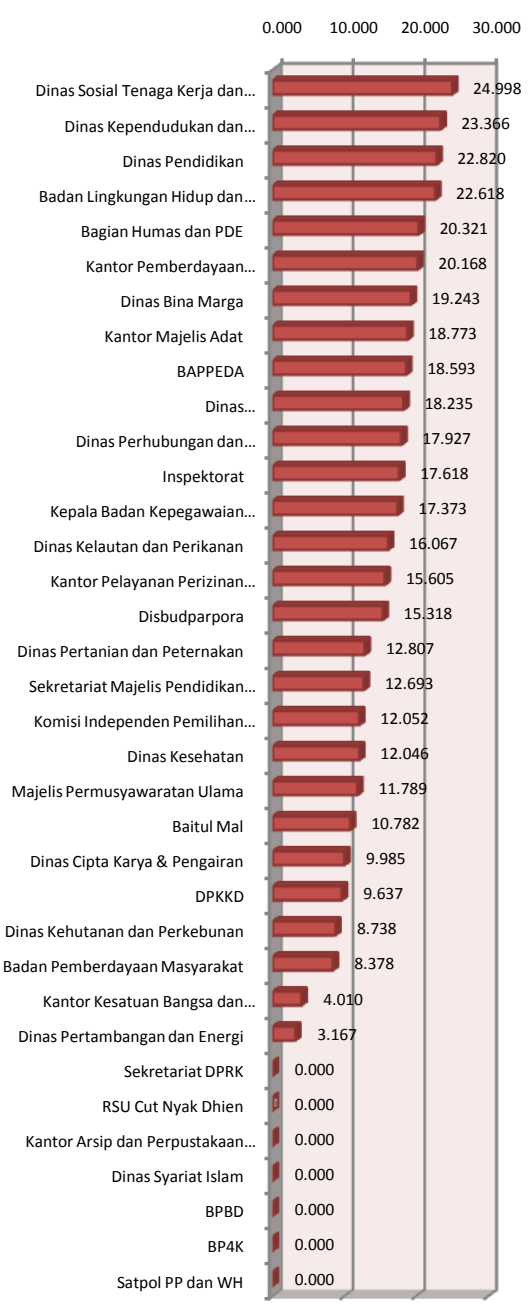

aNilai SAQ

Figure 1: Result of SAQ Assessment on SKPK in Aceh Barat

\section{RESULTS AND DISCUSSION}

Based on the set out stages above, in the first phase researchers distributed questionnaires to the 35 Assistants PPID in West Aceh district. The process is called Self Assessment Questionnaire (SAQ). The questionnaire was filled out independently by the Assistants PPID. The results of that assessment with regard to the information that must be provided by PPID, as the following:
According to the results of the assessment, it is understood that the provision of public information on Asisstants PPID was not maximized. This is indicated by the amount of the resulting value is still below $25 \%$ with 13 variables that must be performed during the service of information to the public. In addition, the lack of values obtained show that Assistants PPID in SKPK Aceh Barat has not yet implemented all the provisions stipulated in the Freedom of 
Information Law and the Perki SLIP. Moreover, there are 7 Assistants PPID of SKPK are not getting value in this SAQ stage, 6 of them not giving answers to the questionnaire and 1 of them not giving the questionnaire back, namely the Assistant PPID of the Dinas Syariat Islam.

Afterward, the researchers conducted a study over the website of each SKPK. The study was carried out during 7 working days, from 12 to 18 October 2016, with the following results:

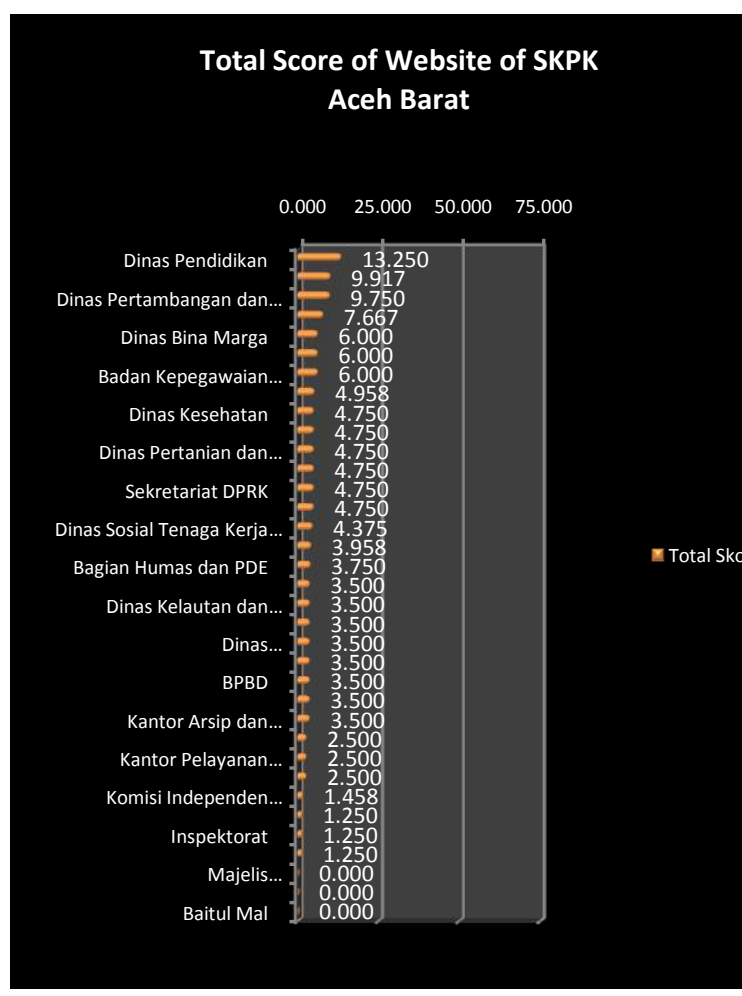

Figure 2 : Result of Assessment on Website of SKPK in Aceh Barat

According to the results of assessment of the PPID website, it is understood that the provision of public information related to 7 (seven) variables still not optimally performed by the Assistants PPID of SKPK. The result value of the website assessment of each Assistant PPID of SKPK in general is still below $15 \%$. It gives a confirmation that the announcement of the necessitate information is still not optimal, as required by the Freedom of Information Law and Perki SLIP. In fact, it was found out that there were 3 (three) Assistants PPID of SKPK that do not have website.

Then, the researchers conducted aggregation of SAQ ratings and website values to rank 10 Assistants PPID of SKPK in Aceh Barat. The results of an aggregate assessment between the SAQ and ratings websites can be seen as follows:

Table: Agregate Value of SAQ dan Website Assessment

\begin{tabular}{|c|c|c|c|c|}
\hline Ranking & Name of Public Agency & SAQ & Website & $\begin{array}{c}\text { SAQ + } \\
\text { Website }\end{array}$ \\
\hline 1 & Dinas Pendidikan & 22.820 & 13.250 & 36.070 \\
\hline 2 & $\begin{array}{l}\text { Kantor Pemberdayaan } \\
\text { Perempuan dan Keluarga } \\
\text { Sejahtera }\end{array}$ & 20.168 & 9.917 & 30.085 \\
\hline 3 & $\begin{array}{l}\text { Dinas Sosial Tenaga Kerja dan } \\
\text { Transmigrasi }\end{array}$ & 24.998 & 4.375 & 29.373 \\
\hline 4 & $\begin{array}{l}\text { Dinas Kependudukan dan } \\
\text { Pencatatan Sipil }\end{array}$ & 23.366 & 3.500 & 26.866 \\
\hline 5 & BAPPEDA & 18.593 & 7.667 & 26.260 \\
\hline 6 & Dinas Bina Marga & 19.243 & 6.000 & 25.243 \\
\hline 7 & $\begin{array}{l}\text { Badan Lingkungan Hidup dan } \\
\text { Kebersihan }\end{array}$ & 22.618 & 2.500 & 25.118 \\
\hline 8 & Bagian Humas dan PDE & 20.321 & 3.750 & 24.071 \\
\hline 9 & $\begin{array}{l}\text { Badan Kepegawaian Pendidikan } \\
\text { dan Pelatihan }\end{array}$ & 17.373 & 6.000 & 23.373 \\
\hline 10 & $\begin{array}{l}\text { Dinas Koperasi, UKM, } \\
\text { Perindustrian dan Perdagangan }\end{array}$ & 18.235 & 3.500 & 21.735 \\
\hline 11 & Dinas Kelautan dan Perikanan & 16.067 & 3.500 & 19.567 \\
\hline 12 & $\begin{array}{l}\text { Dinas Perhubungan dan } \\
\text { Telekomunikasi }\end{array}$ & 17.927 & 1.250 & 19.177 \\
\hline 13 & Inspektorat & 17.618 & 1.250 & 18.868 \\
\hline 14 & Disbudparpora & 15.318 & 3.500 & 18.818 \\
\hline 15 & $\begin{array}{l}\text { Sekretariat Majelis Adat Aceh } \\
\text { (MAA) }\end{array}$ & 18.773 & 0.000 & 18.773 \\
\hline 16 & $\begin{array}{l}\text { Kantor Pelayanan Perizinan } \\
\text { Terpadu }\end{array}$ & 15.605 & 2.500 & 18.105 \\
\hline 17 & $\begin{array}{l}\text { Sekretariat Majelis Pendidikan } \\
\text { Daerah }\end{array}$ & 12.693 & 4.958 & 17.651 \\
\hline 18 & Dinas Pertanian dan Peternakan & 12.807 & 4.750 & 17.557 \\
\hline 19 & Dinas Kesehatan & 12.046 & 4.750 & 16.796 \\
\hline 20 & DPKKD & 9.637 & 6.000 & 15.637 \\
\hline 21 & Dinas Cipta Karya \& Pengairan & 9.985 & 4.750 & 14.735 \\
\hline 22 & $\begin{array}{l}\text { Komisi Independen Pemilihan } \\
\text { (KIP) }\end{array}$ & 12.052 & 1.458 & 13.510 \\
\hline 23 & Dinas Kehutanan dan Perkebunan & 8.738 & 4.750 & 13.488 \\
\hline 24 & Badan Pemberdayaan Masyarakat & 8.378 & 4.750 & 13.128 \\
\hline 25 & Dinas Pertambangan dan Energi & 3.167 & 9.750 & 12.917 \\
\hline 26 & $\begin{array}{l}\text { Sekretariat Majelis } \\
\text { Permusyawaratan Ulama }\end{array}$ & 11.789 & 0.000 & 11.789 \\
\hline
\end{tabular}


Table, continue

\begin{tabular}{|c|l|c|c|c|}
\hline $\mathbf{2 7}$ & Baitul Mal & 10.782 & 0.000 & 10.782 \\
\hline $\mathbf{2 8}$ & $\begin{array}{l}\text { Kantor Kesatuan Bangsa dan } \\
\text { Politik }\end{array}$ & 4.010 & 1.250 & 5.260 \\
\hline $\mathbf{2 9}$ & Sekretariat DPRK & 0.000 & 4.750 & 4.750 \\
\hline $\mathbf{3 0}$ & RSU Cut Nyak Dhien & 0.000 & 3.958 & 3.958 \\
\hline $\mathbf{3 1}$ & $\begin{array}{l}\text { Kantor Arsip dan Perpustakaan } \\
\text { Daerah }\end{array}$ & 0.000 & 3.500 & 3.500 \\
\hline $\mathbf{3 2}$ & Dinas Syariat Islam & 0.000 & 3.500 & 3.500 \\
\hline $\mathbf{3 3}$ & BPBD & 0.000 & 3.500 & 3.500 \\
\hline $\mathbf{3 4}$ & BP4K & 0.000 & 3.500 & 3.500 \\
\hline $\mathbf{3 5}$ & Satpol PP dan WH & 0.000 & 2.500 & 2.500 \\
\hline
\end{tabular}

Next, the aggregate results of the assessment can also be seen as follows:

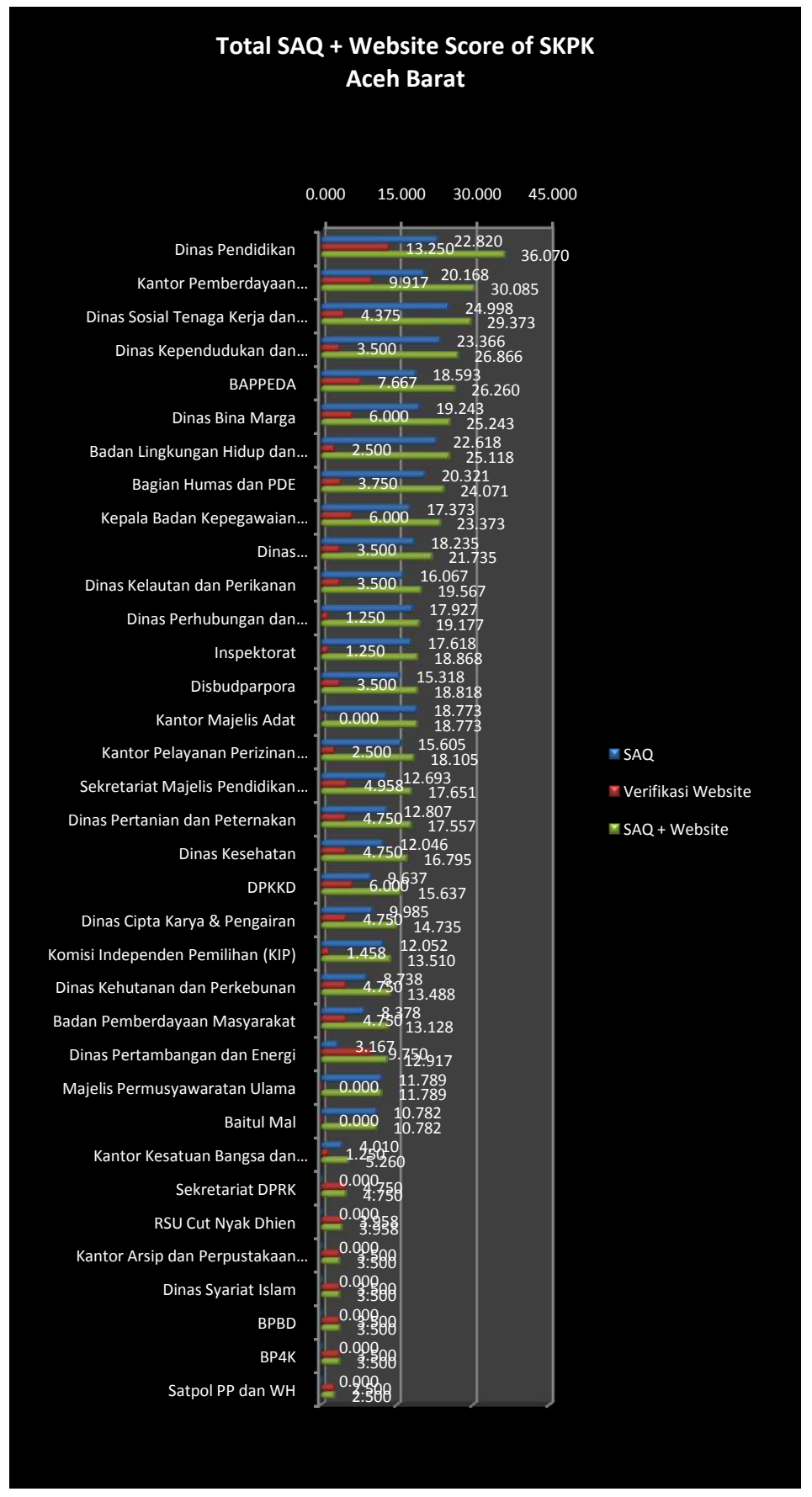

Figure 3: Aggregate Results of the SAQ dan Website Assessment of the SKPK in Aceh Barat.

Furthermore, the result of field visit assessment can be shown as below: 


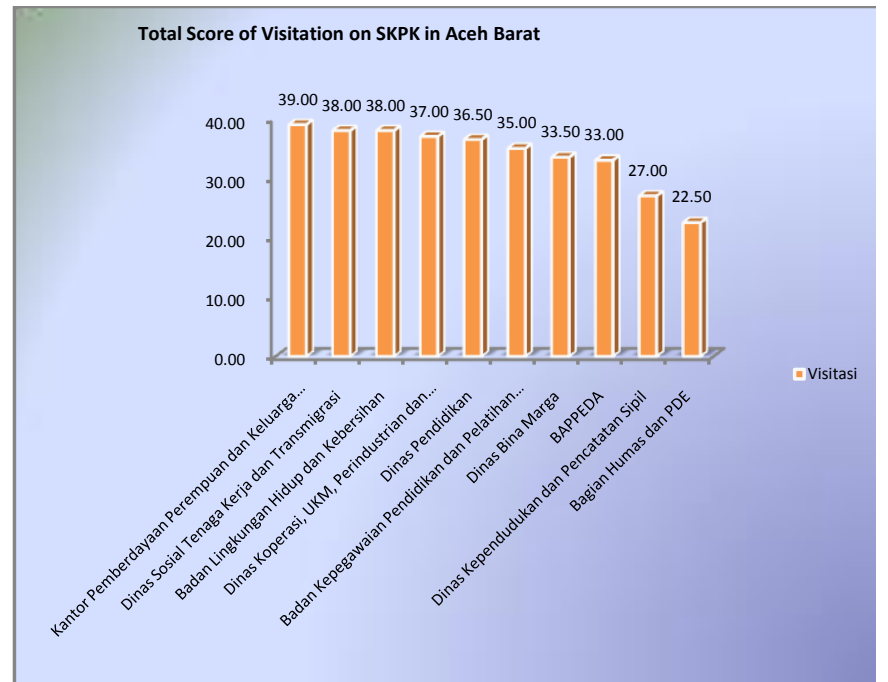

Figure 4: Total Score of Visitation on Assistants PPID of SKPK

While the aggregate value of assessments of the SAQ, website, dan field visit are as the following:

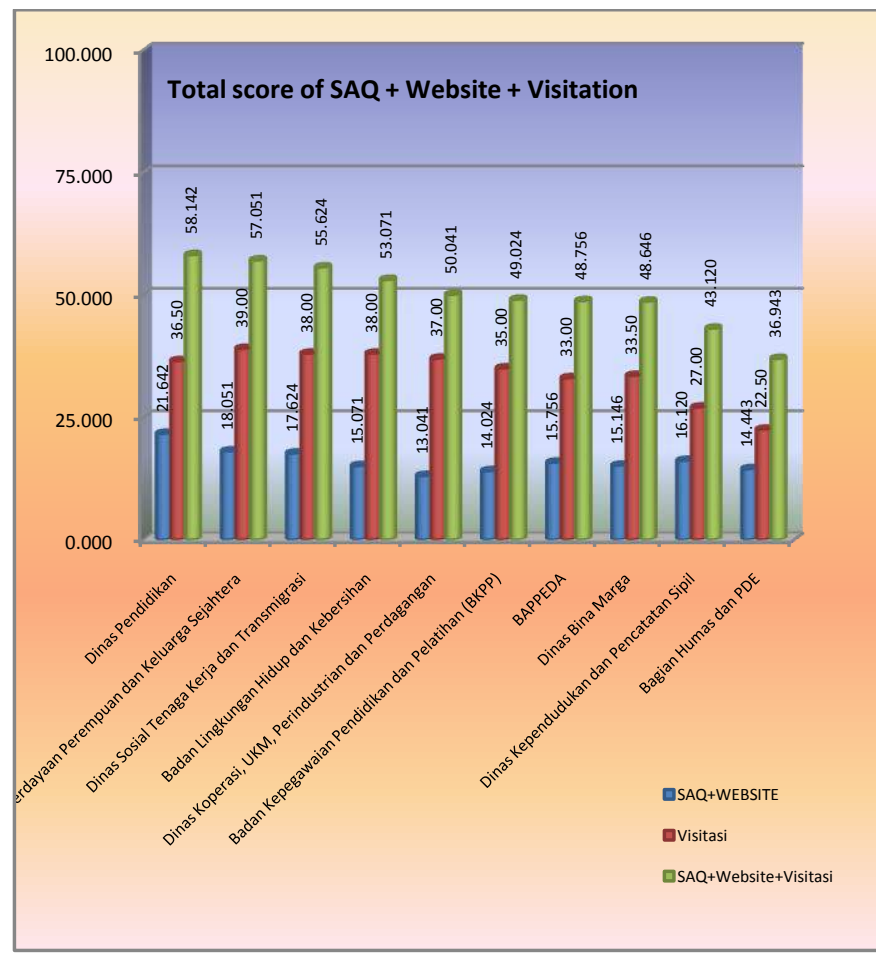

Figure 5: Total Score of SAQ, Website, dan Visitation

Based on the aggregation value above, then the result of the assessment and ranking of the Assistants PPID of SKPK in Aceh Barat as below:

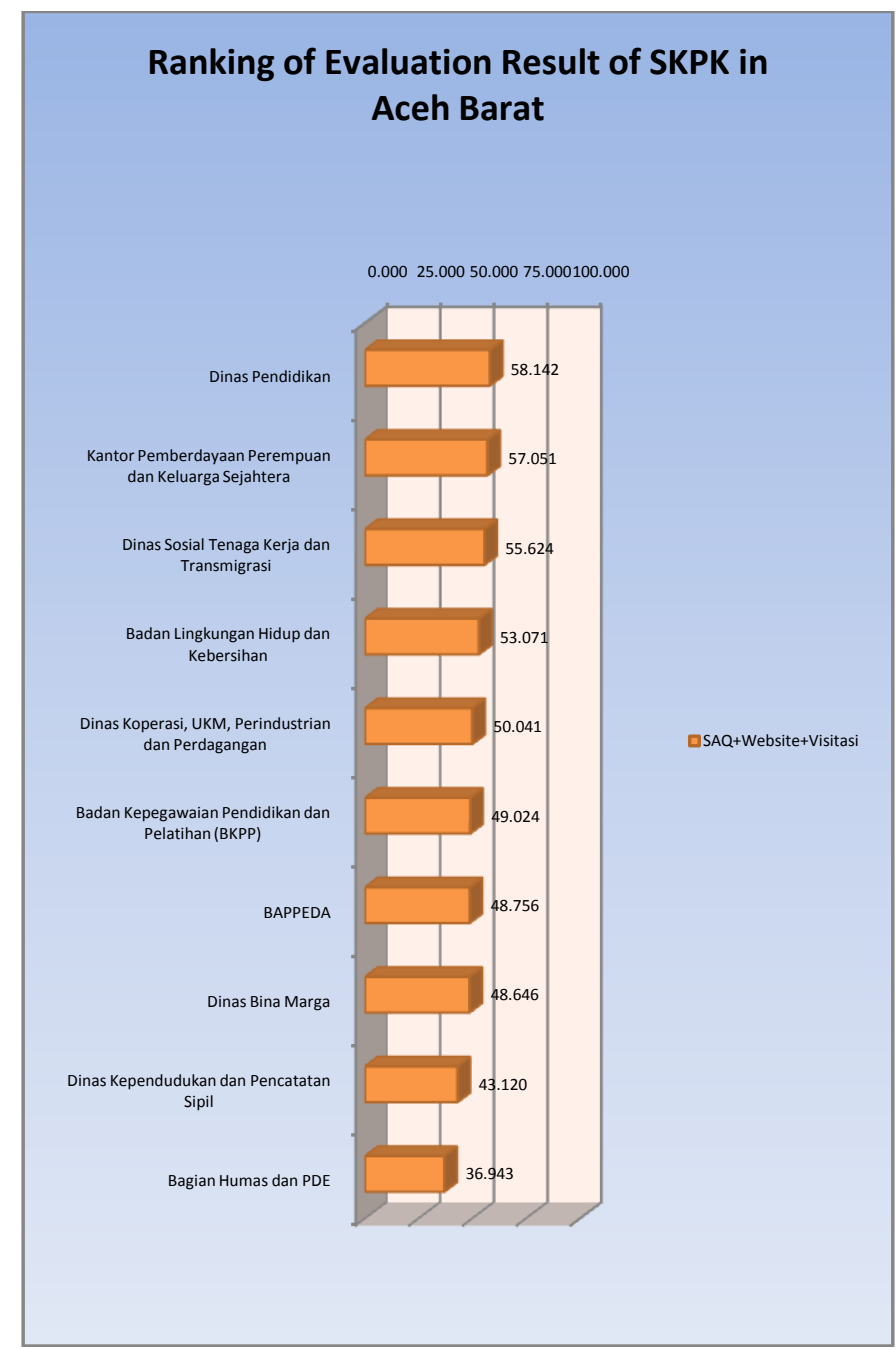

Figure 6: Ranking of Evaluation Result of the Assistants PPID in Aceh Barat

\section{CONCLUSION}

Based on the results of the above assessment, the following conclusions have been obtained:

1. Governance Public Agency Compliance in West Aceh through Assistants PPID in implementing the UU KIP.

Compliance of Assistants PPID in Aceh Barat in implementing the Freedom of Information Law is still lacking. This is indicated by the results of an aggregation assessment between the SAQ and website visit. In general, the combined value is still below $50 \%$, which means there is still a 
public information has not been announced, not provided and, including poor provision of backup facilities of public information services in Aceh Barat. For that, they needed a serious effort to improve the implementation of the Freedom of Information Law to become effective as required by the applicable regulations. Thus, the purpose of establishing the Freedom of Information Law, among others, on the improvement of the quality of public participation can take place in the development in Aceh Barat.

In relation to Katherine dan Susan (1998) who stated that the effectiveness of public participation requires the support of certain resources should be owned by the public and the government, thus we can conclude that the poor public information service at the Assistants PPID of SKPK in Aceh Barat has impacted in the least public participation in the development of Aceh Barat.

2. Several things that may affect compliance of government officials in Aceh Barat district in implementing the UU KIP.

A number of stuffs affecting adherence of apparatus of the Assistants PPID of SKPK in Aceh Barat as follows:

- The importance of coordination among policy-makers (Regent, District Government Secretary, and Main PPID) very helpful to accelerate the implementation of the UU KIP in Aceh Barat.

- Providing reliable human resources with a sufficient amount of personnel highly facilitate compliance of public bodies in implementing the UU KIP.

- Supports for funding and other working facilities very helpful for efforts to to improve the implementation of the Freedom of Information Law in Aceh Barat.

- Changes in behavior and culture of government personnel in Aceh Barat, especially Assistants PPID of SKPK in implementing public information services.

- In addition, public participation to test the access to necessary information has also become an influential factor to improve the service of government officers in West Aceh.

\section{SUGGESTIONS}

To improve the implementation of the Freedom of Information Law in Aceh Barat, a few suggestions for enhancement as follows:

-West Aceh District Government should increase the number and scope of awareness raising campaign about the Freedom of Information Law for Public Agencies and community, both for SKPK, Sub-district Head, as well as Mukim and Gampong.

- Superior Officer of the Main PPID of Aceh Barat District and leaders of other public agency to immediately produce a list of Public Information (DIP) under the Law on Public Information. This is to ensure that the PPID in each public agency can provide information quickly and easily for the applicant.

- Main PPID of Aceh Barat should increase assistance to the Assistant PPID of SKPK, Sub-district and Mukim and Gampong in order to implement the provisions of Freedom of Information Law.

- Main PPID of Aceh Barat deemed necessary to carry out evaluation of the Public Agency regularly over more Public Agencies such as vertical institutions and civil society organizations (CSOs).

- The Government of West Aceh District as well as leaders of other institutions to provide adequate funding support for the implementation of the tasks and functions of the Assistants PPID on SKPK, District and Mukim and Gampong. 


\section{REFERENCES}

Bungin, Burhan, 2008. Penelitian Kualitatif Komunikasi, Ekonomi, Kebijakan Publik, dan Ilmu Sosial Lainnya. Kencana Prenada Media Group: Jakarta.

Katherine A. Graham and Susan D. Philips, 1998. "Making Public Participation More Effective: Issue for Local Government", in KA. Graham and SD Philips (ed) Citizen Engagment: Lesson In Participation From Local Government, The Institute of Public Administration on Canada, Toronto, Ontario, Canada.

Keputusan Bupati Aceh Barat Nomor 619 Tahun 2014 tentang Penunjukkan Pejabat Pengelola Informasi dan Dokumentasi Di Lingkungan Pemerintah Kabupaten Aceh Barat.

Komisi Informasi Aceh, 2013. Laporan Evaluasi Satuan Kerja Perangkat Aceh (SKPA) dan Pemerintah Kabupaten/kota Se Aceh Dalam Pelaksanaan Keterbukaan dan Layanan Informasi Publik, Komisi Informasi Aceh (KIA), Banda Aceh dan Laporan Evaluasi Implementasi Keterbukaan Informasi Publik pada Satuan Kerja Perangkat Aceh, Pemerintah Kabupaten/kota, Perguruan Tinggi Negeri dan Partai Politik di Aceh - Tahun 2015, Komisi Informasi Aceh (KIA), Banda Aceh.

Komisi Informasi Aceh, 2014 dan 2015. Laporan Evaluasi Keterbukaan Informasi Publik di Aceh, Komisi Informasi Aceh (KIA), Banda Aceh.

Komisi Informasi Aceh, 2015. Laporan Evaluasi Implementasi Keterbukaan Informasi Publik pada Satuan Kerja Perangkat Aceh, Pemerintah Kabupaten/Kota, Perguruan Tinggi Negeri dan Partai Politik Di Aceh - Tahun 2015. Komisi Informasi Aceh, Banda Aceh.
Peraturan Komisi Informasi Nomor 1 Tahun 2010 Tentang Standar Layanan Informasi Publik.

Peraturan Gubernur No 39 Tahun 2012 Tentang Pedoman Pengelolaan Informasi dan Dokumentasi Di Lingkungan Pemerintahan Aceh.

Permendagri No 35 Tahun 2010 Tentang Pedoman Pengelolaan dan Pelayanan Informasi Dokumentasi di Lingkungan Depdagri dan Pemerintah Daerah.

Suyanto, Bagong dan Sutinah, 2008. Metode Penelitian Sosial : Berbagai Alternatif Pendekatan, Kencana: Jakarta.

Undang -Undang Nomor 14 Tahun 2008 Tentang Keterbukaan Informasi Publik. 